\title{
Determination of Air Pollutant Concentrations in Plant Species in Relation to Pollution Sources
}

\author{
Lawson Tevi Atator ${ }^{1 *}$, Hodabalo Kamou', Anissou Bawa², \\ Kodjovi Mawuégnigan Léonard Agbodan', Akpisso Aniko Polo', \\ Sêmihinva Ben Akpavi', Koffi Akpagana' \\ ${ }^{1}$ Laboratory of Botany and Plant Ecology, University of Lome, Lomé, Togo \\ ${ }^{2}$ Higher Institute of Agricultural Trades, University of Kara, Kara, Togo \\ Email: ^teviatator@gmail.com, hodabalou@gmail.com, anissou.bawa@univkara.net, agbodana@gmail.com, \\ anikopolo@gmail.com, sakpavi@univ-lome.tg, koffi2100@gmail.com
}

How to cite this paper: Atator, L.T., Kamou, H., Bawa, A., Agbodan, K.M.L., Polo, A.A., Akpavi, S.B. and Akpagana, K. (2021) Determination of Air Pollutant Concentrations in Plant Species in Relation to Pollution Sources. Open Journal of Air Pollution, 10, 53-62. https://doi.org/10.4236/ojap.2021.103004

Received: August 9, 2021

Accepted: September 27, 2021

Published: September 30, 2021

Copyright ( 2021 by author(s) and Scientific Research Publishing Inc. This work is licensed under the Creative Commons Attribution International License (CC BY 4.0).

http://creativecommons.org/licenses/by/4.0/ (c) (i) Open Access

\begin{abstract}
Air quality has been a major health issue in urban areas in recent decades. Human activities release a large number of pollutants into the atmosphere which has a direct impact on plant health and leads to ecosystem degradation. The objective of this study is to contribute to a better evaluation of the impact of the air quality of the city of Togo on biological resources. The determination of pollutants was done on samples of plant species with a strong link with the source of pollution. The determination of Sulfur dioxide $\left(\mathrm{SO}_{2}\right)$ was done by the ripper method. The determination of carbon and estimation of $\mathrm{CO}_{2}$ and $\mathrm{CO}$ by the colorimetric method. The determination of nitrogen was done by the Kjeldhal method. The results showed that at the industrial level the amount of $\mathrm{CO}_{2}$ in Alternanthera repens is high with a value of $53.3911 \mathrm{mg} / \mathrm{ml}$. On the other hand, the quantity of CO in Senna occidentalis is $44.3619 \mathrm{mg} / \mathrm{ml}$. In Pithecellobium dulce, the quantity of $\mathrm{SO}_{2}$ and $\mathrm{NO}_{2}$ are evaluated respectively to $0.1588 \mathrm{mg} / \mathrm{ml}$ and $0.3696 \mathrm{mg} / \mathrm{ml}$. Regarding to the dumps, the quantity of $\mathrm{CO}_{2}$ in Newbouldia laevis is very high with a value of $65.8508 \mathrm{mg} / \mathrm{ml}$. On the other hand the amount of CO in Senna occidentalis is $51.6106 \mathrm{mg} / \mathrm{ml}$. The quantity of $\mathrm{SO}_{2}$ in Newbouldia laevis is $0.2101 \mathrm{mg} / \mathrm{ml}$ and $\mathrm{NO}_{2}$ in Ocimum canum is $0.2744 \mathrm{mg} / \mathrm{ml}$. At the level of roads, the quantities of $\mathrm{CO}_{2}$ and $\mathrm{CO}$ in Eragrostis tenella are very high with values respectively equal to $74.4092 \mathrm{mg} / \mathrm{ml}$ and $62.2654 \mathrm{mg} / \mathrm{ml}$. On the other hand, the amount of $\mathrm{NO}_{2}$ in Amaranthus sp is $0.2304 \mathrm{mg} / \mathrm{ml}$ and that of $\mathrm{SO}_{2}$ in Eragrostis Tenella is $0.1691 \mathrm{mg} / \mathrm{ml}$. The use of a plant bioindicator sensitive to pollutants, allowed concluding that the air of the city of Lome is polluted. The concentration of carbon dioxide and
\end{abstract}


carbon monoxide is much more evident in return when the health of plant species is threatened.

\section{Keywords}

Air Pollution, Anthropogenic Pollution Sources, Bio-Sensitive Species, City of Lomé, Togo

\section{Introduction}

Living organisms are known to reflect environmental conditions according to their sensitivity. This is called biomonitoring, or biological monitoring, using the most sensitive animal or plant species to the pollutants being monitored in their environment. Lichens and mosses are good examples for assessing air pollution [1] [2]. Several approaches have been proposed depending on the observation scale considered [3]. Thus, we distinguish the ecological scale by the biological response of individuals (bio-indication) or communities (bio-integration), from the geochemical scale by the accumulation of contaminant (bioaccumulation). The ecological approach seeks to assess air quality based on the presence/absence of key species in a specific survey (e.g. lichen species). The first scales set up to assess sulfur pollution are no longer appropriate in their present state since the changes in atmospheric contaminants in recent decades [4] [5]. The sensitivity of species must be regularly updated, as already done by [6] towards dominant nitrogen contamination. The analysis of contaminants in an atmospheric deposition is facilitated by the bioaccumulation approach [7]. However, the mechanisms related to the integration of pollutants by plants in Togo and their possible releases are not yet fully documented. For this reason, some plant species were chosen as model organisms in the monitoring of atmospheric contamination in the city of Lomé during the period 2017-2020.

\section{Sampling of Plant Species}

The analysis of the preponderant pollutants in the city of Lomé made it possible to identify sites or sources of pollution presenting high atmospheric concentrations of certain gases. These results coupled with those determining the species having links with these sources allowed to retain the samples of sources of pollutants presenting high values specific to a pollutant. These sites were sampled for plant species related to the source (Figure 1).

Seven (7) species plant with a very strong link to the anthropogenic pollution source were selected for the determination of elements at the Laboratory. They are: Alternanthera repens, Amaranthus sp, Eragrotis tenella, Senna occidentalis, Ocimum canum, Newbouldia laevis, Pithecellobium dulce. These samples were kept cool in minigrip bags to avoid water loss and then sent to the laboratory for chemical analysis. 


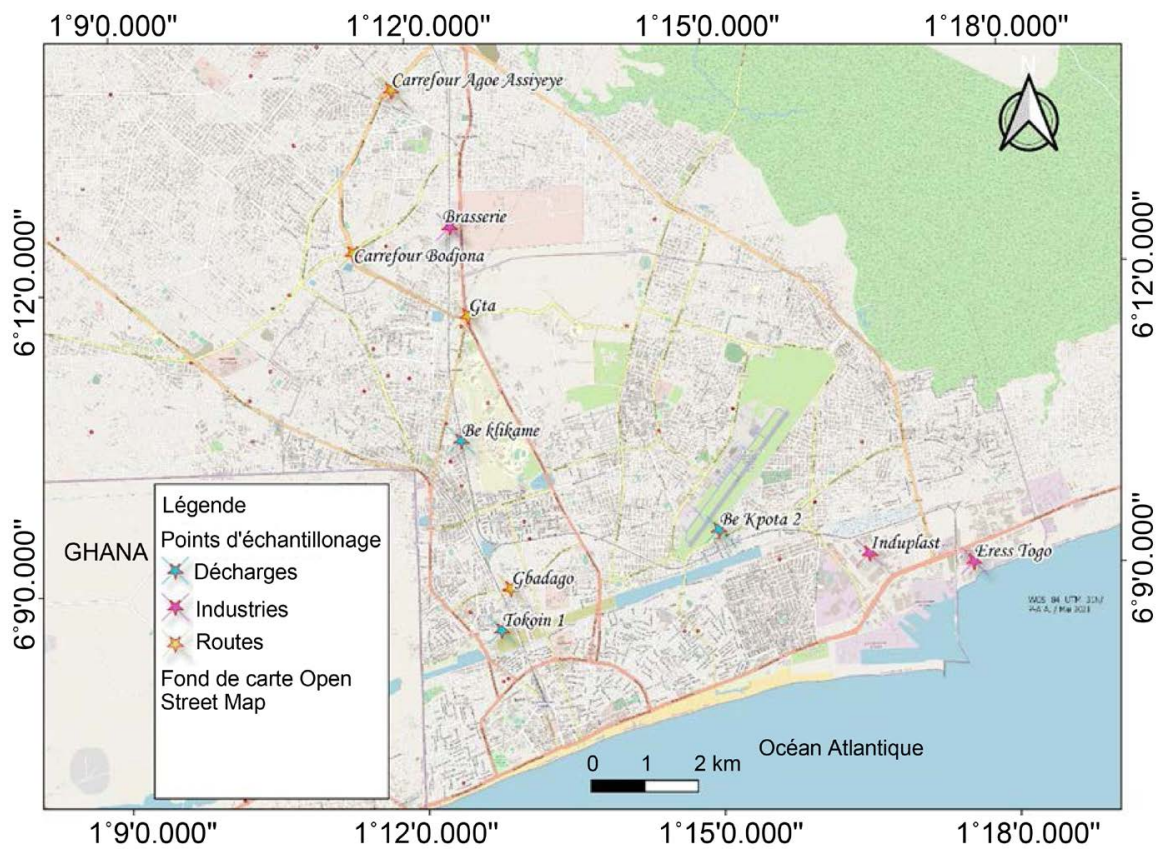

Figure 1. Plant species sampling sites.

\section{Determination of Sulfur Dioxide $\left(\mathrm{SO}_{2}\right)$ by the Ripper Method}

\section{- Principle of determination}

$\mathrm{SO}_{2}$ or sulfur dioxide exists in 2 forms: free and combined. The free form is determined in acid medium by direct iodometric titration and the combined form by the difference between total and free sulfur dioxide. In this analysis, both forms were evaluated. The combined $\mathrm{SO}_{2}$ is hydrolyzed in alkaline medium.

- Procedure for the titration of the iodine solution

Put $25 \mathrm{ml}$ of the iodine solution into a $250 \mathrm{ml}$ Erlenmeyer flask and titrate with the sodium thiosulfate solution until discoloration. $\mathrm{V} \mathrm{ml}$ the volume poured.

- Procedure for the determination of free $\mathrm{SO} 2$

The sample was ground with a molinex added with distilled water. The obtained substrate was poured into an Erlenmeyer of $250 \mathrm{ml}$. The solution obtained was filtered and the filtrate constitutes the plant extract. $15 \mathrm{ml}$ of the plant extract was added with $1 \mathrm{ml}$ of starch starch and about $3 \mathrm{ml}$ of sulfuric acid to $1 / 3$. This was titrated with $0.02 \mathrm{~N}$ iodine until a persistent blue-brown hue appeared $5-10 \mathrm{~s} . \mathrm{N}$ the volume poured.

\section{Procedure for the Determination of $\mathrm{Total}^{\mathrm{SO}_{2}}$}

- Decombination of $\mathrm{SO}_{2}$

$15 \mathrm{ml}$ of the plant extract was poured into a $250 \mathrm{ml}$ Erlenmeyer flask containing about $6 \mathrm{ml}$ of $1 \mathrm{M} \mathrm{NaOH}$. The whole was stoppered and shaken. After 10 min of rest of the solution, $1 \mathrm{ml}$ of starch starch and $2 \mathrm{ml}$ of sulfuric acid to $1 / 3$ were added and titrated with $0.02 \mathrm{~N}$ iodine until a persistent blue-brown hue appeared after 5 to $10 \mathrm{~s}$. Let $\mathrm{N} 1 \mathrm{ml}$ be the volume poured. 
- Total decombination of $\mathrm{SO}_{2}$

In the previous mixture, $24 \mathrm{ml}$ of $\mathrm{NaOH}$ added and stoppered then shake and wait $5 \mathrm{mn} .1 \mathrm{ml}$ of starch starch and $3 \mathrm{ml}$ of sulfuric acid to $1 / 3$ were added. The whole was titrated with $0.02 \mathrm{~N}$ iodine until a persistent purple coloration appeared, i.e. $\mathrm{N} 2 \mathrm{ml}$, the volume poured.

- Iodine titration method

$[\mathrm{I} 2]=\left[\mathrm{Na}_{2} \mathrm{~S}_{2} \mathrm{O}_{3}\right] \times \mathrm{V} \times 1 / 50=0.002 \times \mathrm{V}(\mathrm{mol} / \mathrm{l})$

- Determination of $\mathrm{SO}_{2}$ content

Free $\left[\mathrm{SO}_{2}\right] \mathrm{mg} / \mathrm{l}=64.07 \times[\mathrm{I} 2] \times \mathrm{N} \times 1000 /$ Vext or $\left[\right.$ Free $\left.\mathrm{SO}_{2}\right] \mathrm{mg} / \mathrm{l}=42.71 \times$ $\mathrm{N}\left[\right.$ Total $\left.\mathrm{SO}_{2}\right] \mathrm{mg} / \mathrm{l}=64.07 \times[\mathrm{I} 2] \times(\mathrm{N} 1+\mathrm{N} 2) \times 1000 /$ Vext or $\left[\right.$ Total SO $\left.\mathrm{SO}_{2}\right] \mathrm{mg} / \mathrm{l}=$ $42.71 \times(\mathrm{N} 1+\mathrm{N} 2)\left[\mathrm{SO}_{2} \mathrm{C}\right]=\left[\mathrm{SO}_{2} \mathrm{~T}\right]-\left[\mathrm{SO}_{2} \mathrm{~L}\right]$.

\section{Determination of Carbon and Estimation of $\mathrm{CO}_{2}$ and $\mathrm{CO}$}

\subsection{Colorimetric Method}

Principle of determination: The carbon of the organic matter is oxidized by a mixture of potassium dichromate and sulfuric acid. The blue-green $\mathrm{Cr}^{3+}$ ions formed during the oxidation are determined directly by colorimetry reaction and which are proportional to the equivalents of oxidized carbon. The colorimetric titration curve is made against a glucose solution of known carbon content. Aqueous solution of potassium dichromate and concentrated sulfuric acid were used.

\subsection{Colorimetric Mode of Determination}

A soil sample containing between $0.4 \mathrm{mg}$ and $15 \mathrm{mg}$ of carbon in a $50 \mathrm{ml}$ Erlenmeyer flask was weighed. $5 \mathrm{ml}$ of potassium dichromate and $7.5 \mathrm{ml}$ of concentrated sulfuric acid were added. The whole was covered with a watch glass and then placed in the oven at $105^{\circ} \mathrm{C}$ for three hours. After cooling, distilled water was added and made the volume to $40 \mathrm{ml}$. The whole was shaken and left to decant overnight. A $3500 \mathrm{rpm}$ centrifugation for 10 minutes in a glass tube was done and then weighed with a spectrophotometer at $590 \mathrm{~nm}$. Finally a calibration was done.

\subsection{Expression of Results}

The percentage of carbon is: $\mathrm{C} \%=\mathrm{Lc} / \mathrm{Pe} \times 0.115 \mathrm{With}: \mathrm{Lc}=$ Curve reading in ppm or $\mathrm{mg} / \mathrm{l}, \mathrm{Pe}=$ Weight of soil $(\mathrm{g})$.

According to the equation $\mathrm{C}+\mathrm{O}_{2} \longrightarrow \mathrm{CO}_{2}$; $\left(12 \mathrm{~g} \mathrm{C}\right.$ gives $44 \mathrm{~g} \mathrm{CO}_{2}$ and 28 g CO).

\section{Determination of Nitrogen by the Kjeldhal Method}

\subsection{Principle of Dosage}

The organic matter has been destroyed by oxidizing attack with sulfuric acid. The nitrogen in its various forms is converted into ammonium sulfate in the presence of a selenium catalyst. 


\subsection{Method of Extraction and Determination of Nitrogen}

$0.25 \mathrm{~g}$ of plant powder in a matras was weighed and then added with $50 \mathrm{mg}$ of salicylic acid and 6 glass beads. The matron was shaken and $5 \mathrm{cc}$ of concentrated sulfuric acid was added. The matras was stoppered with a funnel. The whole assembly was allowed to stand overnight. $125 \mathrm{mg}$ of plant catalyst was added and stirred. The whole was left until the residue was perfectly white and then allowed to cool. The funnel in the neck of the matron was removed after rinsing it with a squirt. $40 \mathrm{ml}$ of soda $12 \mathrm{~N}$ was added. The whole was distilled. The distillate was then collected in $25 \mathrm{ml}$ of boric acid in the presence of a turn indicator. The titration was done with $\mathrm{N} / 10$ sulfuric acid. 4 drops of indicator were added and titration with N/10 sulfuric acid until green to red was performed. The results were expressed as mg per $\mathrm{ml}$.

\section{Results}

\subsection{At the Industry Level}

At the industrial level, Alternanthera repens stored more $\mathrm{CO}_{2}$ with a value of $53.3911 \mathrm{mg} / \mathrm{ml}$. On the other hand, Pithecellobium dulce stored more CO with a value of $44.3619 \mathrm{mg} / \mathrm{ml}$. However, $\mathrm{NO}_{2}$ and $\mathrm{SO}_{2}$ are revealed present in Pithecellobium dulce species with low amounts (Figure 2).

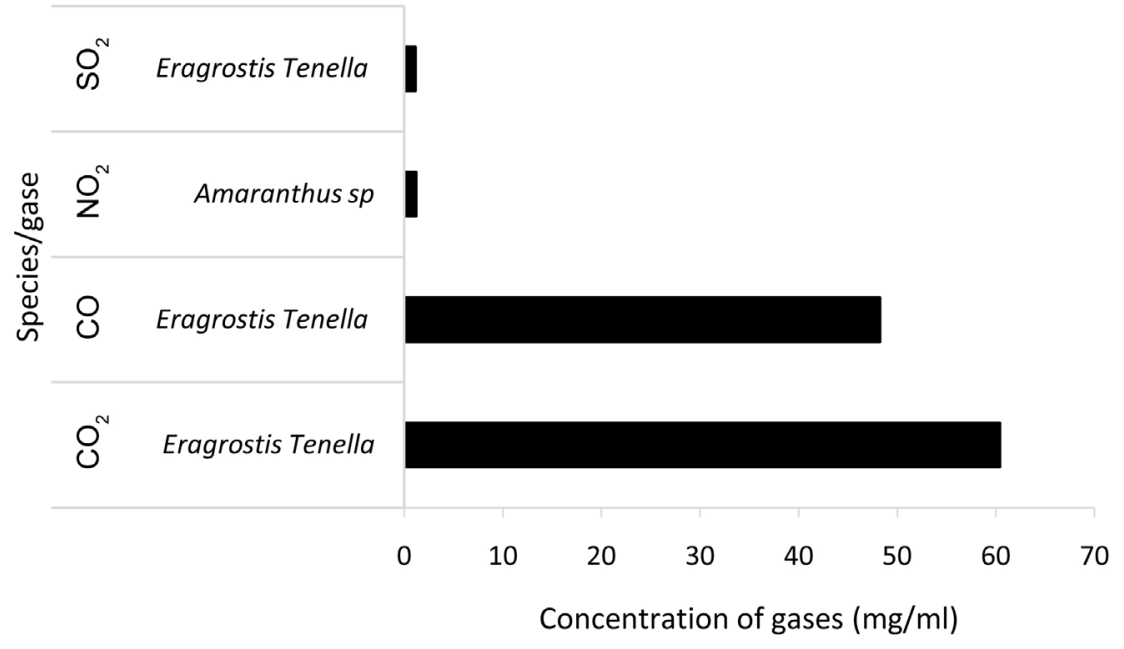

Figure 2. Concentration of the different gases at the level of the species identified at the level of the industries.

\subsection{At the Level of Landfills}

At the level of landfills, Newbouldia laevis stored more $\mathrm{CO}_{2}$ with a value of $65.8508 \mathrm{mg} / \mathrm{ml}$. On the other hand, Senna occidentalis stored more $\mathrm{CO}$ with a value of $51.6106 \mathrm{mg} / \mathrm{ml}$. However, $\mathrm{NO}_{2}$ and $\mathrm{SO}_{2}$ were found to be present in Newbouldia laevis and Ocimum canum with low amounts (Figure 3).

\subsection{At the Road Level}

At the level of roads, Eragrostis Tenella stored more $\mathrm{CO}_{2}$ with a value of 74.4092 
$\mathrm{mg} / \mathrm{ml}$ and $\mathrm{CO}$ with a value of $62.2654 \mathrm{mg} / \mathrm{ml}$. However, $\mathrm{NO}_{2}$ and $\mathrm{SO}_{2}$ were found to be present in Amanranthus sp and Eragrostis Tenella but with low amounts (Figure 4).

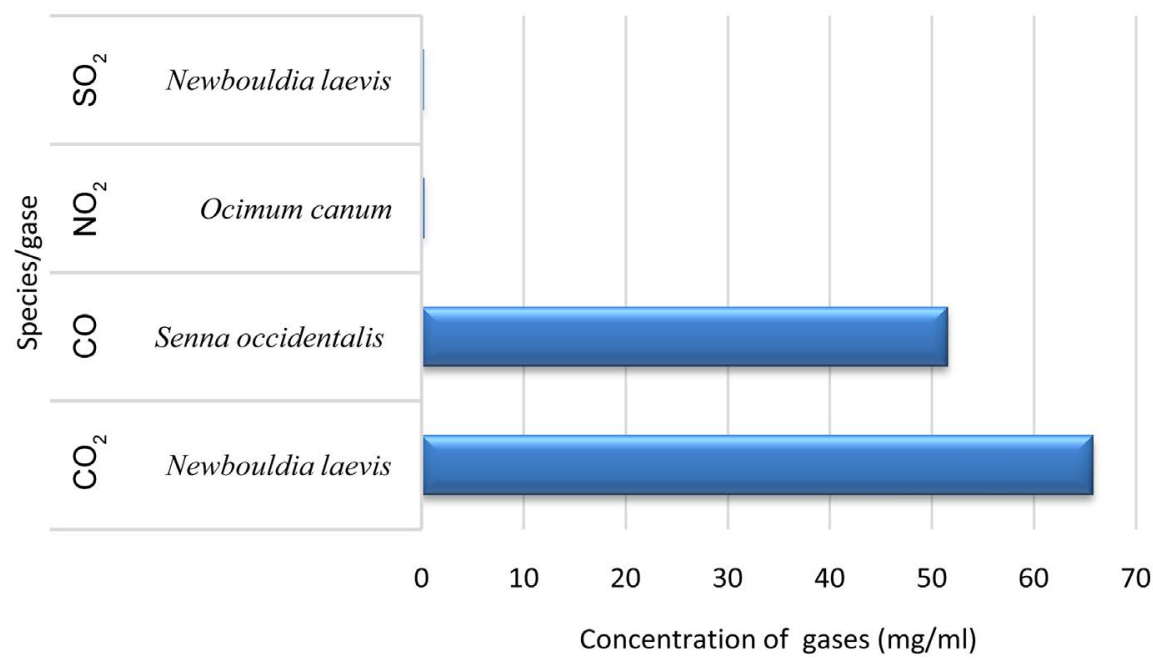

Figure 3. Concentration of the different gases at the level of the species identified at the landfill.

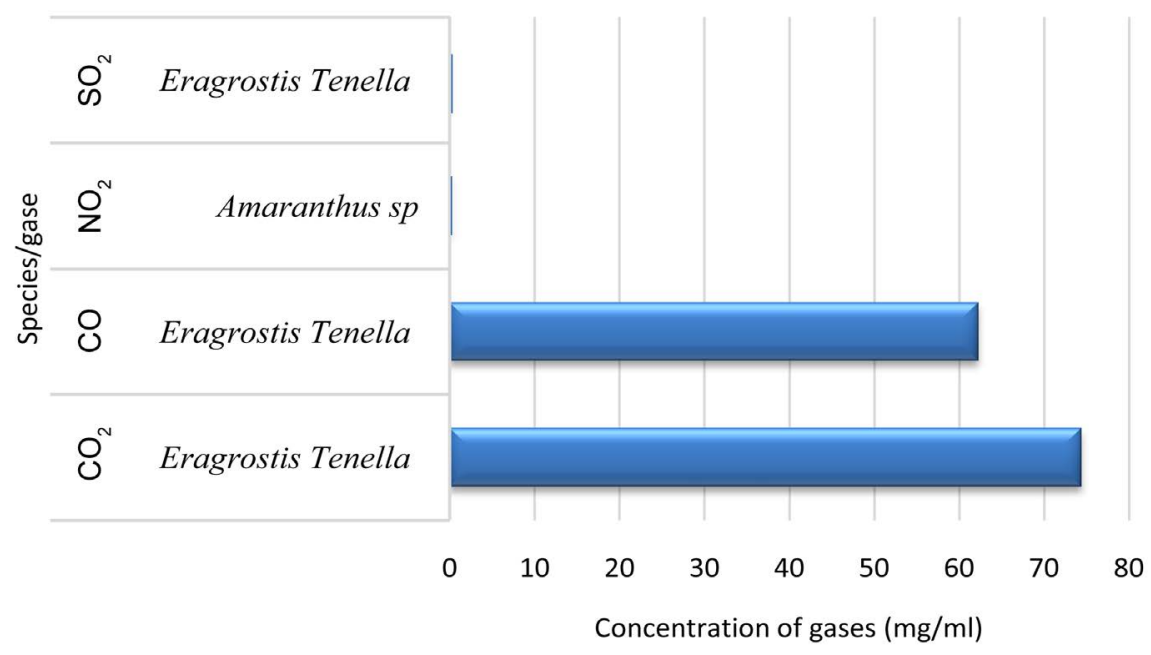

Figure 4. Concentration of the different gases at the level of the species surveyed at the roadsides.

Table 1 and Table 2 present the detailed results of the different plant species analyzed in relation to the specific sources of air pollution. At the level of industries, the amount of $\mathrm{CO}_{2}$ in Alternanthera repens is very high with a value of $53.3911 \mathrm{mg} / \mathrm{ml}$. On the other hand the amount of CO in Senna occidentalis is $44.3619 \mathrm{mg} / \mathrm{ml} /$. At the level of Pithecellobium dulce the quantity of $\mathrm{SO}_{2}$ and $\mathrm{NO}_{2}$ are evaluated respectively to $0.1588 \mathrm{mg} / \mathrm{ml}$ and $0.3696 \mathrm{mg} / \mathrm{ml}$. At the level of the discharges, the quantity of $\mathrm{CO}_{2}$ in Newbouldia laevis is very high with a value of $65.8508 \mathrm{mg} / \mathrm{ml}$. On the other hand the amount of CO in Senna occidentalis is $51.6106 \mathrm{mg} / \mathrm{ml}$. At the level of Newbouldia laevis the amount of 
Table 1. Plant species at sites with high gas-specific values.

\begin{tabular}{|c|c|c|c|c|c|}
\hline \multirow{2}{*}{ Contaminants } & \multirow{2}{*}{ Stations } & \multicolumn{2}{|c|}{ GPS } & \multirow{2}{*}{ Species } & \multirow{2}{*}{$\begin{array}{l}\text { Results } \\
(\mathrm{mg} / \mathrm{ml})\end{array}$} \\
\hline & & $\mathrm{x}$ & $\mathrm{Y}$ & & \\
\hline \multicolumn{6}{|c|}{ Industries } \\
\hline $\mathrm{SO}_{2}$ & Induplast & 680,393 & 309,219 & Pithecellobium dulce (Roxb.) Benth. & 0.1588 \\
\hline $\mathrm{CO}_{2}$ & Brasserie & 686,678 & 301,591 & Alternanthera repens (L.) Link. & 53.3911 \\
\hline $\mathrm{NO}_{2}$ & Brasserie & 686,678 & 301,591 & Pithecellobium dulce (Roxb.) Benth. & 0.3696 \\
\hline $\mathrm{CO}$ & Eress Togo & 680,169 & 311,168 & Pithecellobium dulce (Roxb.) Benth. & 44.3619 \\
\hline \multicolumn{6}{|c|}{ Landfills } \\
\hline $\mathrm{SO}_{2}$ & Bè Kpota 2 & 680,931 & 306,416 & $\begin{array}{l}\text { Newbouldia laevis (P. Beauv.) } \\
\text { Seemann ex Bureau }\end{array}$ & 0.2101 \\
\hline $\mathrm{CO}_{2}$ & Bè Kpota 2 & 680,931 & 306,416 & $\begin{array}{l}\text { Newbouldia laevis (P. Beauv.) } \\
\text { Seemann ex Bureau }\end{array}$ & 65.8508 \\
\hline $\mathrm{NO}_{2}$ & Bè Klikamé & 682,744 & 301,656 & Ocimum canum Sims & 0.2744 \\
\hline $\mathrm{CO}$ & Tokoin 1 & 679,233 & 302,283 & Senna occidentalis (L.) Link & 51.6106 \\
\hline \multicolumn{6}{|c|}{ Roadsides } \\
\hline $\mathrm{SO}_{2}$ & Gta & 6.19447 & 1.20933 & Eragrostis Tenella (linn.) P Beauv. & 0.1691 \\
\hline $\mathrm{CO}_{2}$ & Carrefour Bodjona & 6.20544 & 1.19025 & Eragrostis Tenella (linn.) P Beauv. & 74.4092 \\
\hline $\mathrm{NO}_{2}$ & Carrefour Agoè Assiyéyé & 6.23236 & 1.19765 & Amaranthus sp & 0.2304 \\
\hline $\mathrm{CO}$ & Gbadago & 6.14894 & 1.21504 & Eragrostis Tenella (linn.) P Beauv. & 62.2654 \\
\hline
\end{tabular}

Table 2. Contents of plant species in different chemical elements considered.

\begin{tabular}{|c|c|c|c|c|c|c|c|c|}
\hline \multirow{2}{*}{$\begin{array}{l}\text { Sources of } \\
\text { Pollution }\end{array}$} & \multirow{2}{*}{ Stations } & \multicolumn{2}{|c|}{ GPS } & \multirow{2}{*}{ Species } & \multicolumn{4}{|c|}{ Results (mg/ml) } \\
\hline & & $\mathrm{x}$ & $\mathrm{Y}$ & & $\mathrm{NO}_{2}$ & $\mathrm{SO}_{2}$ & $\mathrm{CO}$ & $\mathrm{CO}_{2}$ \\
\hline \multirow{4}{*}{ Industries } & Induplast & 680,393 & 309,219 & $\begin{array}{l}\text { Pithecellobium dulce } \\
\quad \text { (Roxb.) Benth. }\end{array}$ & 0.381 & 0.159 & 40.522 & 63.7442 \\
\hline & Brasserie & 686,678 & 301,591 & $\begin{array}{l}\text { Alternanthera repens } \\
\text { (L.) Link. }\end{array}$ & 0.283 & 0.174 & 33.94 & 53.3911 \\
\hline & Brasserie & 686,678 & 301,591 & $\begin{array}{l}\text { Pithecellobium dulce } \\
\quad \text { (Roxb.) Benth. }\end{array}$ & 0.37 & 0.185 & 45.074 & 70.9044 \\
\hline & Eress Togo & 680,169 & 311,168 & $\begin{array}{l}\text { Pithecellobium dulce } \\
\text { (Roxb.) Benth. }\end{array}$ & 0.375 & 0.128 & 44.362 & 69.785 \\
\hline \multirow{3}{*}{ Landfills } & Bè Kpota 2 & 680,931 & 306,416 & $\begin{array}{l}\text { Newbouldia laevis (P. } \\
\text { Beauv.) Seem. }\end{array}$ & 0.375 & 0.21 & 41.861 & 65.85 \\
\hline & Bè Klikamé & 682,744 & 301,656 & Ocimum canum Sims & 0.274 & 0.108 & 36.731 & 57.780 \\
\hline & Tokoin 1 & 679,233 & 302,283 & $\begin{array}{c}\text { Senna occidentalis (L.) } \\
\text { Link }\end{array}$ & 0.325 & 0.133 & 51.611 & 81.187 \\
\hline \multirow{4}{*}{ Roadsides } & GTA & 619,447 & 120,933 & $\begin{array}{l}\text { Eragrostis Tenella } \\
\text { (linn. P Beauv. }\end{array}$ & 0.358 & 0.169 & 62.265 & 97.948 \\
\hline & $\begin{array}{l}\text { Carrefour } \\
\text { Bodjona }\end{array}$ & 620,544 & 119,025 & $\begin{array}{l}\text { Eragrostis Tenella } \\
\text { (linn.) P Beauv. }\end{array}$ & 0.952 & 0.226 & 47.302 & 74.409 \\
\hline & $\begin{array}{c}\text { Carrefour } \\
\text { Agoè Assiyéyé }\end{array}$ & 623,236 & 119,765 & Amaranthus sp & 0.23 & 0.292 & 29.491 & 46.392 \\
\hline & Gbadago & 614,894 & 121,504 & $\begin{array}{l}\text { Eragrostis Tenella } \\
\text { (linn.) P Beauv. }\end{array}$ & 0.358 & 0.169 & 62.265 & 97.948 \\
\hline
\end{tabular}


$\mathrm{SO}_{2}$ is $0.2101 \mathrm{mg} / \mathrm{ml}$ and $\mathrm{NO}_{2}$ in Ocimum canum is $0.2744 \mathrm{mg} / \mathrm{ml}$.

At the of level of roads, the quantities of $\mathrm{CO}_{2}$ and $\mathrm{CO}$ in Eragrostis Tenella are very high with values respectively equal to $74.4092 \mathrm{mg} / \mathrm{ml}$ and $62.2654 \mathrm{mg} / \mathrm{ml}$. On the other hand, the amount of $\mathrm{NO}_{2}$ in Amaranthus sp is $0.2304 \mathrm{mg} / \mathrm{ml}$ and that of $\mathrm{SO}_{2}$ in Eragrostis Tenella is $0.1691 \mathrm{mg} / \mathrm{ml}$ (Table 1 and Table 2).

\section{Discussion}

Density of the road traffic, landfills and industries are the source of atmospheric pollution worldwide. Gases produced by anthropogenic sources are in turn captured by some plant species in nature. Among the main gases measured at the level of industries, landfills and roads in the city of Lomé, it was revealed a high concentration of these gases at the level of certain plant species. This is the case of [8] [9] in the USA.

At the industrial level, it was found that Alternanthera repens stored more carbon dioxide $\left(\mathrm{CO}_{2}\right)$ followed by Pithecellobium dulce which stored more carbon monoxide (CO). However, $\mathrm{SO}_{2}$ and $\mathrm{NO}_{2}$ are stored with low concentrations. In Togo, in the city of Lome, industries are among the sources of pollution where carbon dioxide and carbon monoxide are the most released gases in nature. At the level of these industries the most frequent and widespread species are Alternanthera repens and Pithecellobium dulce. These species undergo enormous pressures with respect to the gases that are released into the atmosphere. The presence of these gases in these species really shows that in these industrial areas, the atmosphere is polluted. In these industrial areas, sulfur dioxide and nitrogen dioxide are recorded at the level of these same plant species. Indeed according to several authors $\mathrm{NO}_{2}$ and $\mathrm{SO}_{2}$ are gases which should not be in the atmosphere. The presence of these gases confirms that the industries constitute sources of anthropic pollutions which are to be taken into account. These same studies were carried out on lichens, mosses, tobacco [4] [5] [8] [9] [10] [11]. Indeed, most of these studies cited above have confirmed that lichens and mosses are very sensitive species that can be used to measure the degree of pollution of the atmosphere in a given area.

At the level of landfills, Newbouldia laevis and Senna occidentalis are recognized as species that have more accumulated carbon dioxide and carbon monoxide. In contrast the concentration of $\mathrm{NO}_{2}$ in Ocimum canum low as well as the concentration of sulfur dioxide in Newbouldia laevis. At road level the concentration of carbon dioxide is higher in Eragrostis Tenella and that of carbon monoxide is higher in Amaranthus sp.

The comparison of the levels of these gases in the species shows spatial variations of these gases in the city of Lomé. Unfortunately in Togo, several plant species are used extensively by urban, semi-urban and rural populations. And among these species we can cite Ocimum canum, Newbouldia laevis, Senna occidenttalis, Alternanthera repens, Eragrostis tenella, Pithecellobium dulce. According to the [12] WHO (2005) values, the accumulation of pollutants in plants can cause carcinogenic diseases in human organism. 
Thus, our study on biomonitoring in the city of Togo, carried out from the observation of its effects on these sensitive plants, confirms the influence of urban road traffic density, anthropic activities and climatic conditions. Our results, which are in agreement with ozone data measured continuously by AIRLOR on some urban and suburban sites in France, complete the knowledge of the situation of an important regional agglomeration with respect to these atmospheric pollutants.

\section{Conclusion}

The results showed that at the industrial level the concentration of $\mathrm{CO}_{2}$ in $A I-$ ternanthera repens is high with a value of $53.3911 \mathrm{mg} / \mathrm{ml}$. On the other hand, the quantity of CO in Senna occidentalis is $44.3619 \mathrm{mg} / \mathrm{ml}$. At the level of Pithecellobium dulce, the quantity of $\mathrm{SO}_{2}$ and $\mathrm{NO}_{2}$ are evaluated respectively to 0.1588 $\mathrm{mg} / \mathrm{ml}$ and $0.3696 \mathrm{mg} / \mathrm{ml}$. At the level of the dumps, the amount of $\mathrm{CO}_{2}$ in $\mathrm{New}$ bouldia laevis is very high with a value of $65.8508 \mathrm{mg} / \mathrm{ml}$. On the other hand, the amount of CO in Senna occidentalis is $51.6106 \mathrm{mg} / \mathrm{ml}$. At the level of Newbouldia laevis the amount of $\mathrm{SO}_{2}$ is $0.2101 \mathrm{mg} / \mathrm{ml}$ and $\mathrm{NO}_{2}$ in Ocimum canum is $0.2744 \mathrm{mg} / \mathrm{ml}$. At the level of roads, the quantities of $\mathrm{CO}_{2}$ and $\mathrm{CO}$ in Eragrostis Tenella are very high with values respectively equal to $74.4092 \mathrm{mg} / \mathrm{ml}$ and $62.2654 \mathrm{mg} / \mathrm{ml}$. On the other hand, the amount of $\mathrm{NO}_{2}$ in Amaranthus sp is $0.2304 \mathrm{mg} / \mathrm{ml}$ and that of $\mathrm{SO}_{2}$ in Eragrostis Tenella is $0.1691 \mathrm{mg} / \mathrm{ml}$. The use of a plant bioindicator sensitive to pollutants, allowed concluding that the air of the city of Lome is polluted. The concentration of carbon dioxide and carbon monoxide is much more evident in return the health of plant species is threatened.

\section{Conflicts of Interest}

The authors declare no conflicts of interest regarding the publication of this paper.

\section{References}

[1] Garrec, J.-P. and Van Haluwyn, C. (2002) Biosurveillance végétale de la qualité de l'air. Tec \& Doc, Paris.

[2] Cachon, F.B.A. (2013) Étude de pollution atmosphérique en Afrique Sub-Saharienne: Cas de Cotonou (Bénin): Caractérisation physicochimique des matières particulaires d'origine urbaine et impact toxicologique sur des cellules épithéliales bronchiques humaines (BEAS-2B) cultivées in vitro. Doctoral dissertation, Université du Littoral Côte d'Opale; Université d'Abomey-Calavi (Bénin).

[3] Markert, B.A., Breure, A.M., and Zechmeister, H.G. (2003) Definitions, Strategies and Principles for Bioindication/Biomonitoring of the Environment. In: Trace Metals and Other Contaminants in the Environment, Elsevier, 6, 3-39. https://doi.org/10.1016/S0927-5215(03)80131-5

[4] Dominutti, P., Keita, S., Bahino, J., Colomb, A., Liousse, C., Yoboué, V., Borbon, A., et al. (2019) Anthropogenic VOCs in Abidjan, Southern West Africa: From Source Quantification to Atmospheric Impacts. Atmospheric Chemistry and Physics, 19, 11721-11741. https://doi.org/10.5194/acp-19-11721-2019 
[5] Bahino, J., Yoboué, V., Galy-Lacaux, C., Adon, M., Akpo, A., Keita, S., Djossou, J., et al. (2018) A Pilot Study of Gaseous Pollutants' Measurement $\left(\mathrm{NO}_{2}, \mathrm{SO}_{2}, \mathrm{NH}_{3}\right.$, $\mathrm{HNO}_{3}$ and $\mathrm{O}_{3}$ ) in Abidjan, Côte d'Ivoire: Contribution to an Overview of Gaseous Pollution in African Cities. Atmospheric Chemistry and Physics, 18, 5173-5198. https://doi.org/10.5194/acp-18-5173-2018

[6] Van Haluwyn, C., Cuny, D. and Garrec, J.-P. (2011) Introduction générale-Définitions, concepts et enjeux généraux de la biosurveillance de la qualité de l'air. Pollution Atmosphérique, 3, 7-13.

[7] Agnan, Y. (2013) Bioaccumulation et bioindication par les lichens de la pollution atmosphérique actuelle et passée en métaux et en azote en France: Sources, mécanismes et facteurs d'influence. Doctoral Dissertation.

[8] Galsomiès, L., Ayrault, S., Carrot, F., Deschamps, C. and Letrouit-Galinou, M.A. (2003) Interspecies Calibration in Mosses at Regional Scale-Heavy Metal and Trace Elements Results from Ile-de-France. Atmospheric Environment, 37, 241-251.

https://doi.org/10.1016/S1352-2310(02)00831-2

[9] Freer-Smith, P.H., El-Khatib, A.A. and Taylor, G. (2004) Capture of Particulate Pollution by Trees: A Comparison of Species Typical of Semi-Arid Areas (Ficus Nitida and Eucalyptus Globulus) with European and North American Species. Water, Air, and Soil Pollution, 155, 173-187. https://doi.org/10.1023/B:WATE.0000026521.99552.fd

[10] Bargagli, R., Monaci, F., Borghini, F., Bravi, F. and Agnorelli, C. (2002) Mosses and Lichens as Biomonitors of Trace Metals. A Comparison Study on Hypnum Cupressiforme and Parmelia Caperata in a Former Mining District in Italy. Environmental Pollution, 116, 279-287. https://doi.org/10.1016/S0269-7491(01)00125-7

[11] Garrec, J.P. and Livertoux, M.H. (2016) Bioindication végétale de l'ozone dans l'agglomération nancéienne durant l'été 1996. 2268-3798.

[12] World Meteorological Organization (2012) WMO Greenhouse Gas Bulletin: The State of Greenhouse Gases in the Atmosphere Based on Global Observations through 2011. 